pressed his enthusiasm for the high quality of the mirror which arrived recently from England.

The AAT will be fully operational by January 1975 . The cost of establishing the AAT by then will have been $\$ \mathrm{~A}$ 16 million, shared equally between the United Kingdom and Australia. The AAT board has recently announced its estimates of the running costs: these will rise to $\$ \mathrm{~A} 1.74$ million per annum in 1976-77 before steadying out at $\$ \mathrm{~A}$ 1.3 million per annum in following years. Professor Wampler's salary has not been announced.

In Australian scientific circles, there is much relief that these two projects in growth areas of Australian research can move into high gear at last, though there has been disappointment among local scientists that none of their number won either of these key posts.

The temporary nature of Professor Wampler's initial appointment underscores the uncertainty which has hung over the running of the AAT, as distinct from its design and construction which proceeded smoothly. There was much heartache over whether the Australian National University would have any special place in running the astronomical programme of the largest telescope on the site of their own Sliding Spring Observatory: the university lost on this point. The head of its Department of Astronomy, Professor Olin Eggen resigned from the AAT board last year. After protracted discussions, the AAT board, with equal representation of three Australian and three British nominees, did not settle on one of their own world class nationals as director. But, at least the AAT board has determined a policy of observing time being equally divided between British and Australian astronomers-under a tactful director of neutral nationality.

\section{Oxfam solves a sewage problem}

\section{John Wilson}

IN the hope of cutting down on infections caused by insanitary conditions in refugee camps Oxfam, the famine relief organisation, has commissioned original scientific research and is well on the way to developing an entirely novel kind of sewage disposal. Already it has arrived at a system which scores over conventional equipment by being cheap, easily transported, and capable of erection by unskilled labour. It may also result in the elimination of the organisms responsible for cholera and dysentry by containing sewage in anaerobic conditions.

Oxfam's interest in a sewage system was first kindled by its experience of the refugee camps in Bengal at the time of the Indo-Pakistan war of 1971. Oxfam realised that most of its relief effort was often spent on the treatment of diseases resulting from insanitary conditions within the camps and that in many instances the preventive medicine used was not very effective in controlling these diseases-particularly cholera.

Containment of the sewage is a priority, so Oxfam looked for a suitable container. It considered using a portable fuel tank, developed by the Royal Air Force (RAF) as part of its back-up facilities for the harrier, and found that it would provide almost instantaneous anaerobic conditions. From this sprang the idea of destroying the pathogens anaerobically.

In the event, Oxfam found that the RAF tank had some shortcomings and decided instead to pass the effluent along a flexible tube about 100 feet long and 5 feet in diameter. This can be rolled up for transport and easily partitioned for the sedimentation of solid matter. Moreover, by sampling the effluent as it moves along the tube a ready estimate of the survival of pathogens can be made.

The water pollution research laboratory at Stevenage advised on the general design of a unit suitable for about 5,000 people, but there was one important fact that the Stevenage laboratory did not know. The survival time of the cholera vibrio in anaerobic sewage had never been determined, so it was not clear how long the sewage would have to be retained to eliminate the organism. Oxfam asked Mr B. Lloyd, of the University of Surrey, to study the retention problem.

With the assistance of a student, $\mathrm{Mr}$ Lloyd found that the survival of the organism depends on the temperature of the sludge. No cholera vibrios were found when the effluent was maintained at $37^{\circ} \mathrm{C}$ for 7 days but when the temperature was lowered to $25^{\circ} \mathrm{C}$ they took 12 days to disappear. In his final report to Oxfam, Mr Lloyd recommended that the sewage should be retained in anaerobic conditions for at least a fortnight. This piece of research cost Oxfam £50.

With a grant of $£ 19,000$ from the Leverhulme Trust, Oxfam next set about trying the system under operational conditions. They sent a microbiologist and two engineers to Bangladesh at the beginning of the year and on the evidence of their visit it is Iikely that there will be a large scale test project at a Bihari refugee camp in Muhamadpur, Dacca, in the near future. An extra $£ 6,000$ is needed before the plan can go ahead, but there is a suggestion that the government may come forward with the money. With the evidence of such enterprise on the part of a registered charity, it can scarcely do otherwise.

\section{Setback for space science}

Colin Norman, Washington

A LAUNCH vehicle designed to be NASA's chief workhorse for planetary flights in the $1970 \mathrm{~s}$, had to be blown up during its test flight last week. The rocket, a Titan-Centaur, was destroyed over the Atlantic when the Centaur stage failed to ignite. A board of inquiry has been set up to try to determine the cause of the failure, but from preliminary data, it seems that a boost pump failed to supply necessary pressure to the Centaur engines.

The episode has caused some consternation among planetary scientists, because the Titan-Centaur is designed to launch six important missions in the next few years-two Helios spacecraft to study the Sun, two Viking missions to Mars, and two Mariner spacecraft on a flyby mission around Jupiter and Saturn. If the failure is deemed serious enough to require a second test mission before the launch vehicle is entrusted with an expensive spacecraft, some of those missions may have to be delayed.

NASA officials last week were hopeful, however, that a second test flight will not be necessary, and that the first Helios launch can take place on schedule in September. According to $\mathrm{Mr}$ Joseph Mahon, director of NASA's launch vehicle and propulsion programmes, the flight provided much valuable information as far as it went, and many pieces of hardware specifically under test functioned perfectly. The guidance system, for example, which is located in the Centaur stage took the Titan stage on the correct course, and the shroudthe only major piece of equipment that had not been flown before on other rockets-jettisoned successfully.

The flight also provided data on the environment in the spacecraft section as it went through the lower reaches of the atmosphere, which is essential for the planning of future missions. Thus Mahon predicted that if the board of inquiry can pinpoint the failure exactly, then "we can launch Helios with a $99.9 \%$ certainty that it will function properly".

The failure itself occurred some eight minutes into the flight, as the vehicle was passing out of range of the Kennedy Space Center's tracking equipment. Thus it was not possible to tell with any certainty exactly what went wrong unili data were relayed back from tracking stations further down line.

Apart from the Centaur rocket itself, its payload, consisting of a model of the Viking lander, and a spacecraft designed to measure the effect of charged particles on solar cells, was also blown to pieces. 